\title{
Model Pengembangan Pasar Tradisional Berbasis Pada Perilaku Konsumen
}

\author{
Wahyu Hidayat ${ }^{1}$, Widiartanto $^{2}$, Apriatni Endang Prihartini ${ }^{3}$ dan Reni Shinta Dewi ${ }^{4}$ * \\ ${ }^{1,2,3,4}$ Departemen Administrasi Bisnis, Fakultas Ilmu Sosial dan Ilmu Politik, Universitas Diponegoro \\ *Email: renishinta@yahoo.co.id
}

\begin{abstract}
This study aims to determine the factors that shape the traditional market development model based on consumer behavior. The study was conducted at Peterongan Market in Semarang City with a sample of 100 traders using Cluster Purposive Sampling and 100 buyers using Accidental Sampling. Data was collected using interviews with 2 key informants from the Market Service using Snowball Sampling. Data was processed using Factor Analysis and Regression Analysis using SPSS 16. The results of the analysis show that the Development of Peterongan Market must be based on consumer behavior, in addition to the regional regulations of Semarang City. Through consumer behavior, we can find out the desires of the consumers of Peterongan Market who are the boosters for traders to continue developing their businesses to meet consumer needs. Traders need a place or facility to transact with consumers in a comfortable, clean and well-organized. For this reason, the government has a big role to facilitate the needs of traders and consumers by build a clean, comfortable, orderly and well-organized market buildings.
\end{abstract}

\begin{abstract}
Abstraksi Penelitian ini bertujuan untuk mengetahui faktor-faktor yang membentuk model pengembangan pasar tradisional berbasis pada perilaku konsumen. Penelitian dilakukan di Pasar Peterongan di Kota Semarang dengan mengambil sampel sebanyak 100 pedagang dengan teknik pengambilan sampel Cluster Purposive Sampling dan 100 orang pembeli dengan teknik pengambilan sampel Acidental Sampling. Adapun untuk mengetahui pengembangan pasar tradisional, maka data diambil dengan menggunakan wawancara dengan 2 key informan yang berasal dari Dinas Pasar dengan teknik pengambilan sampel Snowball Sampling. Data yang telah terkumpul kemudian diolah dengan menggunakan Analisis Faktor dan Uji Analisis Regresi dengan bantuan SPSS 16. Hasil analisis menunjukkan bahwa Pembangunan Pasar Peterongan harus berbasis dari perilaku konsumen, disamping berbasis peraturan daerah Kota Semarang. Melalui perilaku konsumen dapat diketahui bagaimana keinginan para konsumen di Pasar Peterongan yang menjadi pemacu pedagang untuk terus mengembangkan usahanya demi memenuhi kebutuhan konsumen. Pedagang membutuhkan tempat atau sarana bertransaksi dengan konsumen secara nyaman, bersih dan teratur. Untuk itu pemerintah memiliki peran besar untuk memfasilitasi kebutuhan pedagang dan konsumen dengan membangun bangunan pasar yang bersih, nyaman, tertib, dan teratur.
\end{abstract}

Keywords: Trader; Buyer; Market Service; Consumer Behavior-based Market

\section{Pendahuluan}

Di Indonesia, pasar tradisional masih merupakan wadah utama masyarakat dalam membeli suatu kebutuhan selain itu juga merupakan wadah dalam penjualan produkproduk berskala ekonomi rakyat seperti: petani, nelayan, pengrajin dan home industry (industri rumah tangga). Interaksi sosial di dalam pasar tradisional sangat kelihatan, ini dapat dibuktikan dari tata cara penjualan (sistem tawar menawar) sampai dengan ragam latar belakang suku dan ras didalamnya (Bappeda, 2010). Selain itu keberadaan pasar tradisional bukan semata urusan ekonomi tapi lebih jauh kepada norma, budaya, sekaligus peradaban yang berlangsung sejak lama di berbagai wilayah di Indonesia.

Di Indonesia pangsa pasar dan kinerja usaha pasar tradisional menurun, sementara pada saat yang sama pasar modern mengalami peningkatan setiap tahunnya. Kontribusi pasar tradisional sekitar $69,9 \%$ pada 2007 , menurun dari tahun sebelumnya (2006) sekitar 73,7\%. Kondisi sebaliknya terjadi pada Supermarket dan Hypermarket, kontribusi mereka kian hari kian besar. Pada 2006 kontribusi pasar modern sebesar 26,3\% mengalami kenaikan pada tahun berikutnya, 2007 menjadi $30,1 \%$ (AC. Nielsen, 2007). 
Selama ini kehadiran pasar modern selalu dipertentangkan dengan keberadaan pasar tradisional sebagai dua kutub yang berbeda. Berbelanja di pasar modern lebih mudah dengan fasilitas yang serba lengkap dan dikelola dengan professional. Pasar modern juga memiliki pelayanan yang lebih menarik daripada pasar tradisional, serba instan dengan kemasan yang lebih baik sehingga barangbarang yang bersifat mudah rusak (perishable) dan tahan lebih lama meski dengan harga yang sedikit lebih mahal (Kusdarjito, 2009). Sedangkan di pasar tradisional masih dihadapkan dengan ketidaknyamanan berbelanja. Hasil studi sebelumnya yang dilakukan oleh Ekapribadi (2007) menyebutkan ada beberapa kelemahan yang dimiliki pasar tradisional. Kelemahan tersebut telah menjadi karakter dasar yang sangat sulit di ubah. Faktor desain dan tampilan pasar, atmosfir, tata ruang, tata letak, keragaman dan kualitas barang, promosi pengeluaran, jam operasional pasar yang terbatas, serta optimalisasi pemanfaatan ruang jual merupakan kelemahan terbesar pasar tradisional dalam menghadapi persaingan dengan pasar modern.

Menurunnya animo masyarakat untuk berbelanja di pasar tradisional dapat dilihat pada tabel 1. di bawah ini:

\section{Tabel 1. Rasio Keinginan Berbelanja Masyarakat di Pasar Tradisional dan Pasar Modern Tahun 1999- 2004}

\begin{tabular}{lcccccc}
\hline Tahun & $\mathbf{1 9 9 9}$ & $\mathbf{2 0 0 0}$ & $\mathbf{2 0 0 1}$ & $\mathbf{2 0 0 2}$ & $\mathbf{2 0 0 3}$ & $\mathbf{2 0 0 4}$ \\
\hline Pasar & $65 \%$ & $63 \%$ & $60 \%$ & $52 \%$ & $56 \%$ & $53 \%$ \\
$\begin{array}{l}\text { Tradisional } \\
\text { Pasar }\end{array}$ & $35 \%$ & $37 \%$ & $40 \%$ & $43 \%$ & $44 \%$ & $47 \%$ \\
Modern & & & & & \\
\hline Sumber: & AC Nielson Asia Pasific & Retail and \\
& Shopper Trend (2005) & &
\end{tabular}

Menurunnya minat masyarakat untuk berbelanja di pasar tradisional selain disebabkan karena kurang berkembangnya pasar tradisional, juga dipengaruhi oleh minimnya daya dukung karakteristik pedagang tradisional (Wiboonpongse dan Sriboonchitta, 2006). Hal ini diperkuat dengan temuan penelitian yang dilakukan oleh Paesoro (2007), penyebab utama kalah bersaingnya pasar tradisional dengan pasar modern adalah lemahnya manajemen dan buruknya infrastruktur pasar tradisional, bukan semata-mata karena keberadaan supermarket. Supermarket sebenarnya mengambil keuntungan dari kondisi buruk yang ada di pasar tradisional (Trisno, 2011).

Namun demikian, pasar tradisional juga memiliki beberapa keunggulan dalam pelayanan bersaing secara alamiah seperti lokasi yang strategis, area penjualan yang luas, keragaman barang yang lengkap, harga yang rendah, sistem tawar-menawar yang menunjukkan keakraban antara penjual dan pembeli yang merupakan keunggulan yang dimiliki oleh pasar tradisional (Antara Jateng, 2010).

Fenomena modernisasi dan globalisasi ini terjadi di hampir semua perkotaan di Indonesia, tidak terkecuali Kota Semarang. Pada tahun 2010, jumlah pasar yang dimiliki Pemerintah Kota Semarang yang dikenal dengan pasar tradisional adalah sejumlah 67 pasar yang tersebar di seluruh Kota Semarang (Bappeda, 2010). Sedangkan, jumlah pasar modern, sampai dengan tahun 2010 tercatat sejumlah 723 unit (Bappeda, 2010).

Salah satu pasar tradisional di Kota Semarang adalah Pasar Peterongan. Lokasi pasar Peterongan yang berada di tengahtengah perumahan penduduk dengan tingkat kepadatan cukup tinggi merupakan masalah tersendiri, selain kesulitan lahan untuk pengembangan pasar juga sirkulasi di sekitar pasar menjadi semakin tidak teratur oleh aktivitas warga. Alih fungsi zona pemukiman menjadi area komersial tersebut terlihat pada kawasan perumahan di sekitar Pasar Peterongan yang berubah menjadi deretan pertokoan, bahkan di wilayah tersebut kini telah terdapat dua buah pasar modern multistories dengan hadirnya "Superindo" mendampingi supermarket "Java Supermall" yang telah ada sebelumnya, serta berdirinya swalayan "Ramai", toko grosir " Anugerah" dan mewabahnya minimarket Indomaret dan Alfamart di sekitar pasar Peterongan yang mendorong munculnya persaingan. Untuk itu tujuan penelitian adalah untuk mengetahui faktor-faktor yang dapat dapat membentuk model pengembangan pasar berbasis pada 
perilaku konsumen, sehingga diharapkan pasar tradisional dapat bersaing dengan pasar modern.

\section{Kajian Teori}

\section{Perilaku Konsumen}

Pengertian perilaku konsumen menurut Shiffman dan Kanuk (2004) adalah "Consumer behavior can be defined as the behavior that customer display in searching for, purchasing, using, evaluating, and disposing of products, services, and ideas they expect will satisfy they needs". Selain itu perilaku konsumen menurut Loudon dan Della Bitta (1993) adalah: "Consumer behavior may be defined as the decision process and physical activity individuals engage in when evaluating, acquiring, using, or disposing of goods and services". Dapat dijelaskan perilaku konsumen adalah proses pengambilan keputusan dan kegiatan fisik individu-individu yang semuanya ini melibatkan individu dalam menilai, mendapatkan, menggunakan, atau mengabaikan barang-barang dan jasa-jasa. Menurut Kotler (1997) keputusan pembelian sangat dipengaruhi oleh faktor kebudayaan, sosial, pribadi dan psikologi dari pembeli.

\section{Faktor Budaya}

Faktor budaya memberikan pengaruh paling luas dan dalam pada perilaku konsumen. Perusahaan harus mengetahui peranan yang dimainkan oleh budaya, sub budaya dan kelas sosial pembeli. Budaya adalah penyebab paling mendasar dari keinginan dan perilaku seseorang. Budaya merupakan kumpulan nilai-nilai dasar, persepsi, keinginan dan perilaku yang dipelajari oleh seorang anggota masyarakat dari keluarga dan lembaga penting lainnya.

\section{Faktor Sosial}

Perilaku konsumen juga dipengaruhi oleh faktor sosial, seperti kelompok kecil, keluarga serta peranan dan status sosial konsumen. Perilaku seseorang dipengaruhi oleh banyak kelompok kecil. Kelompok yang mempunyai pengaruh langsung. Definisi kelompok adalah dua orang atau lebih yang berinteraksi untuk mencapai sasaran individu atau bersama.

Keluarga dapat mempengaruhi perilaku pembelian. Keluarga adalah organisasi pembelian konsumen yang paling penting dalam masyarakat. Keputusan pembelian keluarga, tergantung pada produk, iklan dan situasi.

\section{Faktor Pribadi}

Keputusan pembelian juga dipengaruhi oleh karakteristik pribadi seperti umur dan tahapan daur hidup, pekerjaan, situasi ekonomi, gaya hidup, serta kepribadian dan konsep diri pembeli. Konsumsi seseorang juga dibentuk oleh tahapan siklus hidup keluarga. Beberapa penelitian terakhir telah mengidentifikasi tahapan-tahapan dalam siklus hidup psikologis. Orang-orang dewasa biasanya mengalami perubahan atau transformasi tertentu pada saat mereka menjalani hidupnya. Pekerjaan mempengaruhi barang dan jasa yang dibelinya. Para pemasar berusaha mengidentifikasi kelompokkelompok pekerja yang memiliki minat di atas rata-rata terhadap produk dan jasa tertentu.

Situasi ekonomi seseorang akan mempengaruhi pemilihan produk. Situasi ekonomi seseorang terdiri dari pendapatan yang dapat dibelanjakan (tingkatnya, stabilitasnya, dan polanya), tabungan dan hartanya (termasuk presentase yang mudah dijadikan uang). Gaya hidup seseorang adalah pola hidup di dunia yang diekspresikan oleh kegiatan, minat dan pendapat seseorang. Gaya hidup menggambarkan "seseorang secara keseluruhan" yang berinteraksi dengan lingkungan. Gaya hidup juga mencerminkan sesuatu dibalik kelas sosial seseorang.

Kepribadian adalah karakteristik psikologis yang berada dari setiap orang yang memandang responnya terhadap lingkungan yang relatif konsisten. Kepribadian dapat merupakan suatu variabel yang sangat berguna dalam menganalisa perilaku konsumen. Bila jenis- jenis kepribadian dapat diklasifikasikan dan memiliki korelasi yang kuat antara jenis-jenis kepribadian tersebut 
dengan berbagai pilihan produk atau merek.

\section{Faktor Psikologis}

Pemilihan barang yang dibeli seseorang lebih lanjut dipengaruhi oleh empat faktor psikologis, yaitu motivasi, persepsi, pembelajaran dan kepercayaan. Motivasi merupakan kebutuhan yang cukup menekan untuk mengarahkan seseorang mencari cara untuk memuaskan kebutuhan tersebut. Persepsi didefinisikan sebagai proses dimana seseorang memilih, mengorganisasikan, mengartikan masukan informasi untuk menciptakan suatu gambaran yang berarti dari dunia ini. Pembelajaran menjelaskan perubahan dalam perilaku seseorang yang timbul dari pengalaman. Sedang kepercayaan merupakan suatu pemikiran deskriptif yang dimiliki seseorang terhadap sesuatu.

\section{Faktor Marketing Strategy}

Merupakan variabel dimana pemasar mengendalikan usahanya dalam memberitahu dan mempengaruhi konsumen (Kotler,1997). Variabel-variabelnya adalah: (1) Barang ; (2) Harga; (3) Periklanan; (4) Distribusi yang mendorong konsumen dalam proses pengambilan keputusan.

\section{Perkembangan Usaha}

Kinerja perusahaan didefinisikan sebagai kemampuan perusahaan untuk membuat tindakan dan hasil yang dapat diterima (Peffer \& Salancik, 1978). Namun kinerja perusahaan harus dapat dikonsepkan dan diopersionalisasikan, serta dapat diukur dalam beberapa cara. Alasadi dan Abdelrahim (2007) menyatakan kinerja pada UKM dapat dilihat dari kepuasan pemilik/manajer (dependen variabel) atas: profit, omset, tahap balik modal (Break Even Point), dan pengembangan usaha. Akan tetapi Menurut Dess et al. pengukuran kinerja hanya dengan menekankan aspek keuangan punya kelemahan, misalnya tak mampu mengukur kinerja harta-harta tak tampak (intangible assets) dan harta-harta intelektual (sumber daya manusia) perusahaan. Hal senada dikemukakan Kaplan dan Norton yang menegaskan bahwa kinerja keuangan tidak mampu "bicara banyak" tentang masa lalu perusahaan atau tidak otomatis membawa perusahaan ke arah yang lebih baik (Riyanti, 2003).

Orang yang berhasil dalam berwirausaha adalah orang yang dapat menggabungkan nilai, sifat utama (pola sikap), dan perilaku dengan bekal pengetahuan, pengalaman, dan ketrampilan praktis. Jadi, pedoman, pengharapan, dan nilai, baik yang berasal dari pribadi maupun kelompok, berpengaruh dalam membentuk perilaku kewirausahaan sehinga menentukan keberhasilan usahanya nanti.

Zimmerer (1996) mengemukakan beberapa faktor yang menyebabkan wirausaha gagal dalam menjalankan usaha barunya, yaitu: (1) Tidak kompeten dalam hal manajerial. Tidak kompeten atau tidak memiliki kemmapuan dan pengetahuan mengelola usaha merupakan faktor penyebab utama yang membuat perusahaan kurang berhasil ; (2) Kurang berpengalaman, baik dalam kemampuan teknik, memvisualisasikan usaha, mengoordinasikan, mengelola sumber daya manusia, dan mengintregasikan operasi perusahaan; (3) Kurang dapat mengendalikan keuangan. Agar perusahaan dapat berhasil dengan baik, faktor yang paling utama dalam keuangan adalah memlihara aliran kas, mengatur pengeluaran dan penerimaan secara cermat. Kekeliruan dalam pemeliharaan aliran kas akan menghambat operasional perusahaan dan mengakibatkan perusahaan tidak lancar ;(4) Gagal dalam perencanaan. Perencanaan merupakan titik awal dari suatu kegiatan, sekali gagal dalam perencanaan maka akan mengalami kesulitan dalam pelaksanaan ;(5) Lokasi yang kurang memedai. Lokasi usaha yang strategis merupakan faktor yang menentukan keberhasilan usaha. Lokasi yang tidak strategis dapat mengakibatkan perusahaan sukar beroperasi karena kurang efisien ;(6) Kurangnya pengawasan peralatan. Pengawasan erat kaitannya dengan efisiensi dan efektivitas. Kurangnya pengawasan dapat mengakibatkan penggunaan peralatan (fasilitas) perusahaan secara tidak efisien dan tidak efektif; (7) Sikap yang kurang sungguhsungguh dalam berusaha. Sikap yang setengah-setengah terhadap usaha akan mengakibatkan usaha yang dilakukan menjadi 
labil dan gagal. Dengan sikap setengah hati, kemungkinan terjadinya gagal menjadi lebih besar ; (8) Ketidakmampuan dalam melakukan peralihan/ transisi kewirausahaan. Wirausaha yang kurang siap menghadapi dan melakukan perubahan tidak akan menjadi wirausaha yang berhasil. Keberhasilan dalam berwirausaha hanya diperoleh apabila berani mengadakan perubahan dan mampu membuat peralihan setiap waktu.

\section{Metode}

Penelitian ini tergolong pada penelitian deskriptif asosiatif, dimana penelitian ini dilakukan untuk menggambarkan fenomena yang terjadi pada pasar tradisional yang dilihat dari sudut pembeli, penjual, dinas terkait dan kemudian dapat ditunjukkan hubungan dari ketiganya, serta disusun sebuah model pengembangan pasar yang berbasis pada perilaku konsumen. Penelitian ini dilakukan di Kota Semarang dengan mengambil lokasi di Pasar Peterongan, dengan waktu penelitian selama 8 bulan. Populasi dalam penelitian ini adalah pembeli, pedagang dan Dinas Pasar Kota Semarang, dengan perincian sampel sebagai berikut: (1) pembeli diambil sebanyak 100 pembeli yang berbelanja di Pasar Peterongan dengan teknik pengambilan sampel Acidental Sampling; (2) pedagang sebanyak 100 penjual yang berjualan di Pasar Peterongan dengan teknik pengambilan sampel Cluster Purposive Sampling; (3) Dinas Pasar Kota Semarang 2 Key Informan dengan teknik pengambilan sampel Snowball Sampling. Adapun variabel yang diamati dalam penelitian ini adalah (1) Faktor-faktor yang mempengaruhi konsumen berbelanja di pasar tradisional; (2) Faktorfaktor yang mempengaruhi perkembangan usaha pedagang di Pasar Tradisional; dan (3) Kebijakan pengembangan pasar tradisional di Kota Semarang. Analisis data dilkukan dengan menggunakan tabel distribusi frekuensi yang kemudian dianalisis secara kualitatif. Untuk menganalisis faktor-faktor yang mempengaruhi akan dilakukan dengan uji analisis faktor, dan kemudian dilakukan uji regresi dengan bantuan SPSS.

\section{Hasil}

Berdasarkan hasil analisis faktor diatas terlihat semua fator yang membentuk variabel dapat dianalisis untuk melihat pengaruh antar variabel baik dari pembeli ataupun dari pedagang. Adapun dari faktor pembeli untuk menguji pengaruh sosial budaya pribadi, psikologis dan bauran pemasaran terhadap keputusan pembelian yang dapat dilihat pada tabel 2.

Tabel 2. Uji Hasil Regresi Linear Berganda

\begin{tabular}{|c|c|c|c|c|c|c|}
\hline \multicolumn{2}{|c|}{ Model } & \multicolumn{2}{|c|}{$\begin{array}{l}\text { Unstandardized } \\
\text { Coefficients }\end{array}$} & \multirow{2}{*}{$\begin{array}{c}\text { Standardized } \\
\text { Coefficients }\end{array}$} & \multirow[t]{2}{*}{$\mathrm{T}$} & \multirow[t]{2}{*}{ Sig. } \\
\hline & & B & Std. Error & & & \\
\hline \multirow[t]{4}{*}{1} & (Constant) & .391 & .251 & & 1.561 & .122 \\
\hline & Sosbudpri & .233 & .104 & .246 & 2.250 & .027 \\
\hline & Psikologis & .251 & .106 & .257 & 2.366 & .020 \\
\hline & Bauran_pemasaran & .393 & .122 & .368 & 3.234 & .002 \\
\hline
\end{tabular}

A. Dependent Variable: Keputusan_Pembelian

Hasil analisis menunjukkan bahwa semua variabel mempengaruhi keputusan pembelian ulang konsumen di Pasar Peterongan Semarang, dengan nilai sig. $<0,05$.

Adapun dari faktor pedagang untuk menguji pengaruh faktor modal psikologis entrepreneur, karakteristik entrepreneur, inovasi, manajemen sumber daya manusia, karakteristik UKM terhadap perkembangan usaha dapat dilihat pada tabel 3 . 
Tabel 3. Uji Hasil Regresi Linear Berganda

\begin{tabular}{|c|c|c|c|c|c|c|}
\hline \multirow{2}{*}{\multicolumn{2}{|c|}{ Model }} & \multicolumn{2}{|c|}{$\begin{array}{l}\text { Unstandardized } \\
\text { Coefficients }\end{array}$} & \multirow{2}{*}{$\begin{array}{c}\begin{array}{c}\text { Standardized } \\
\text { Coefficients }\end{array} \\
\text { Beta } \\
\end{array}$} & \multirow[t]{2}{*}{$\mathrm{t}$} & \multirow[t]{2}{*}{ Sig. } \\
\hline & & $\mathrm{B}$ & Std. Error & & & \\
\hline \multirow{6}{*}{1} & (Constant) & -3.090 & 1.623 & & -1.904 & .060 \\
\hline & Psikologis & .254 & .070 & .217 & 3.600 & .001 \\
\hline & Karakteristik_entrepreneur & .107 & .061 & .151 & 1.751 & .083 \\
\hline & Inovasi & .142 & .091 & .146 & 1.562 & .122 \\
\hline & MSDM & .299 & .042 & .573 & 7.054 & .000 \\
\hline & Karakteristik_UKM & .407 & .127 & .309 & 3.219 & .002 \\
\hline
\end{tabular}

a. Dependent Variable: Pengembangan_Usaha Sumber: Data primer, diolah (2015)

Hasil analisis menunjukkan bahwa variabel yang mempengaruhi perkembangan usaha adalah variabel MSDM dengan nilai sig. 0,000 , variabel psikologis dengan nilai sig. 0,001 , dan variabel karakteristik UKM dengan nilai sig. 0,002 .

\section{Pembahasan}

Berdasarkan hasil wawancara dengan Kepala Bidang Pembangunan Dinas Pasar Kota Semarang, menjelaskan bahwa Pasar Peterongan dikelola dan dibangun oleh Pemerintah Kota Semarang melalui Dinas Pasar. Pasar ini diperuntukkan pedagang lama dan berdomisili di Kota Semarang. Pedagang tidak dipungut biaya apapun dalam hal pembangunan pasar tersebut. Setelah dibangun akan ada penataan kembali mengenai letak dan tata ruang Pasar Peterongan. Pemerintah Kota Semarang menginginkan Pasar Peterongan mampu menampung semua pedagang dan menjadi pasar yang memiliki ruang terbuka dan tidak mencemari lingkungan sekitar baik saat pembangunan kembali maupun pasca pembangunan. Hal ini dipertegas oleh hasil wawancara dengan Bapak Prayitno selaku perwakilan dari Bidang Kebersihan Dinas Pasar Kota Semarang pada 8 Juli 2015. Beliau menjelaskan pasar tersebut akan dibangun menjadi dua lantai dengan tata letak yang baru dan diselaraskan dengan peraturan pemerintah daerah. Pasar akan dibangun menjadi 2 lantai, dimana di lantai dasar menjadi ruang terbuka, hal ini dikarenakan letak pasar yang berdampingan dengan saluran air dari warga sekitar. Di lantai pertama digunakan untuk kios dan los pedagang ikan, sembako, buah, dan bumbu dapur. Sedangkan di lantai kedua akan dijadikan tempat kios pakaian, konveksi, dan toko mas. Pemerintah berupaya pembangunan pasar ini tidak merusak bangunan yang menjadi konservasi Kota Semarang.

Pembangunan Pasar Peterongan ini tidak terlepas dari keinginan pedagang yang akan menghuni pasar tersebut. Berdasarkan hasil analisis faktor yang dilakukan pada seratus responden pedagang Pasar Peterongan diperoleh bahwa pedagang memiliki modal psikologis sebagai pengusaha, karakteristik pengusaha, inovasi, manajemen sumber daya manusia, dan karakteristik usaha para pedagang yang mampu mendorong terjadinya pengembangan usaha. Melalui pedagang yang inovatif, berjiwa pengusaha, dan pengelolaan sumber daya manusia yang baik mampu ikut berperan aktif dalam pembangunan Pasar Peterongan. Keinginan dari pedagang ini disampaikan dan ditampung oleh pemerintah sebagai pertimbangan pembangunan pasar dikemudian hari.

Model pengembangan pasar tradisional yang berbasis perilaku konsumen dapat dibangun dengan memperhatikan faktor-faktor berikut: (1) dari sisi pembeli, faktor yang harus lebih mendapat perhatian adalah faktor bauran pemasaran dimana faktor bauran pemasaran merupakan faktor eksternal pembeli yang tidak bisa dikontrol. Adapun faktor bauran pemasaran tersebut adalah kelengkapan produk yang ditawarkan, selain itu kesegaran barang dan kualitas yang ditawarkan juga menjadi daya tarik pembeli untuk kembali ke Pasar Peterongan. Adapun dari sisi harga meski diakui agak mahal, hal ini disebabkan posisi Pasar Peterongan yang berada di tengah kota dan dihimpit oleh pasar modern. Pemberian hadiah pun rutin 
dilakukan pedagang kepada konsumen loyalnya setiap kali hari raya, namun pemberian potongan harga jarang diberikan kepada konsumen yang membeli produk dalam jumlah yang besar. Faktor berikutnya adalah faktor psikologis, hasil analisis menunjukkan bahwa faktor psikologis konsumen terhadap pasar Peterongan Semarang tergolong tinggi. Menurut Kotler (1997) pemilihan barang yang dibeli seseorang lebih lanjut dipengaruhi oleh empat faktor psikologis, yaitu motivasi, persepsi, pembelajaran dan kepercayaan. Motivasi merupakan kebutuhan yang cukup menekan untuk mengarahkan seseorang mencari cara untuk memuaskan kebutuhan tersebut. Persepsi didefinisikan sebagai proses dimana seseorang memilih, mengorganisasikan, mengartikan masukan informasi untuk menciptakan suatu gambaran yang berarti dari dunia ini. Pembelajaran menjelaskan perubahan dalam perilaku seseorang yang timbul dari pengalaman. Sedang kepercayaan merupakan suatu pemikiran deskriptif yang dimiliki seseorang terhadap sesuatu. Hasil penelitian menunjukkan bahwa kepercayaan menjadi faktor utama yang mendorong tingginya faktor psikologis, yaitu adanya rasa percaya dari diri pembeli bahwasanya mutu produk di pasar peterongan yang tidak kalah dengan pasar modern selain sehingga mereka bersedia untuk kembali lagi, selain itu juga kepercayaan pembeli atas ukuran timbangan yang dilakukan oleh penjual. Pada faktor sosial budaya dan pribadi, bahwasanya keputusan pembelian juga dipengaruhi oleh karakteristik pribadi seperti umur dan tahapan daur hidup, pekerjaan, situasi ekonomi, gaya hidup, serta kepribadian dan konsep diri pembeli. Selain itu keputusan pembelian dipengaruhi oleh faktor sosial, seperti kelompok kecil, keluarga serta peranan dan status sosial konsumen. Pada faktor budaya. Budaya adalah penyebab paling mendasar dari keinginan dan perilaku seseorang. Budaya merupakan kumpulan nilai-nilai dasar, persepsi, keinginan dan perilaku yang dipelajari oleh seorang anggota masyarakat dari keluarga dan lembaga penting lainnya (Kotler, 1997). Hasil penelitian menunjukkan bahwa faktor budaya dan pribadi menjadi penentu dari faktor sosial budaya pribadi, dimana usia yang menjadi pertimbangan pembeli untuk berbelanja di Pasar Peterongan, selain itu pendidikan dan penghasilan juga menjadi pertimbangan dari pembeli untuk berbelanja di Pasar Tradisional. Adapun berbelanja di pasar tradisional masih dianggap sebagai budaya mengingat responden dari penelitian ini sebagian besar adalah pedagang $40 \%$. Adapun pada faktor sosial dimana berbelanja di pasar peterongan bukan merupakan pengalaman yang diturunkan dari orang tua. Hal ini disebabkan dalam berbalanja, konsumen menyesuaikan dengan kebutuhan dari mereka masing-masing, apakah untuk keperluan pribadi ataupun untuk keperluan berjualan, sehingga pendidikan mereka tidak akan mempengaruhi bagaimana mereka akan melakukan pembelian di pasar Peterongan.

Adapun faktor lain yang dapat membangun pasar tradisional berbasis perilaku konsumen adalah: (2) dari sisi pedagang, dengan melihat perkembangan usaha dari pedagang. Peningkatan perkembangan usaha secara otomatis akan meningkatkan pelayanan kepada pembeli/konsumen dan akan berorientasi menjadi pasar yang berbasis pada perilaku konsumen. Dari hasil analisis dapat dilihat bahwasanya faktor MSDM menjadi faktor yang mendorong perkembangan usaha, mengingat usaha yang dijalankan di Pasar Tradisional adalah usaha kecil menengah maka pertumbuhan sumber daya manusia menjadi indikator yang mendorong perkembangan usaha, adapun dari indikator yang mendorong pertumbuhan sumber daya manusia adalah kemampuan pemilik untuk melakukan komunikasi dan memberikan motivasi kepada pegawainya terutama dalam hal melayani pembeli/konsumen. Faktor Modal Psikologis Entrepreneur juga menjadi faktor yang mendorong perkembangan usaha. Pada hasil analisis terlihat bahwasanya pedagang di Pasar Peterongan memiliki modal psikologis yang tinggi, dimana modal psikologis tersebut diantaranya adalah optimis, daya tahan terhadap persoalan, bekerja keras, pandangan ke depan dan berani mengambil resiko. Adanya modal psikologis ini akan mendorong pedagang untuk selalu menyediakan kebutuhan pembeli sesuai dengan permintaan dan selalu memberikan pelayanan yang memuaskan bagi pembeli agar mau kembali lagi atau bahkan 


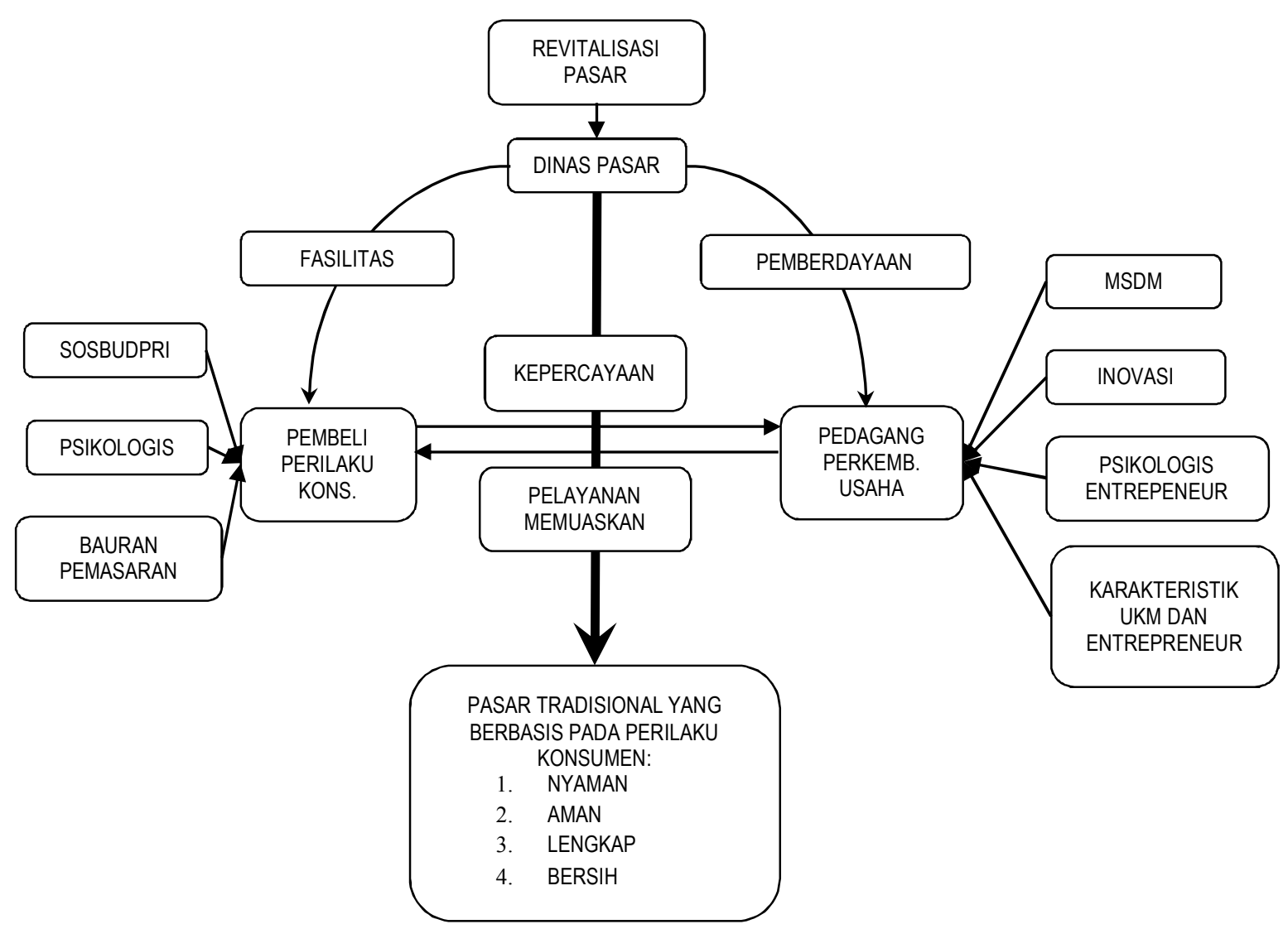

\section{Gambar 1. Model Pengembangan Pasar Tradisional Berbasis Perilaku Konsumen}

merekomendasikan kepada teman, keluarga atau koleganya. Faktor lainnya yang mendorong perkembangan usaha adalah faktor karakteristik Entrepreneur, dimana pada faktor ini pengalaman dan pendidikan menjadi faktor penentu keberhasilan suatu usaha. Pengalaman akan memberikan pelajaran bagi pedagang untuk menemukan cara terbaik agar usaha yang dirintis semakin berkembang, sedangakan pendidikan memberikan wawasan yang lebih luas dalam setiap pengambilan keputusan yang dibutuhkan dalam menghadapi berbagai persoalan yang berhubungan dengan perkembangan usaha.

Selain faktor-faktor yang telah disebutkan oleh pedagang tersebut, berdasarkan hasil wawancara dengan pedagang bahwasanya pembeli langganannya akan tetap berbelanja di pasar tradisional karena beberapa alasan yaitu: (a) sebagian besar langganan adalah golongan masyarakat menengah ke bawah; (b) biasanya pembelian barang dalam jumlah yang sangat kecil/ngecer; (c) hubungan antara pedagang dan pembeli cukup akrab dan saling percaya, sehingga memungkinkan pembeli melakukan pembelian secara kredit/nyicil/hutang; (d) adanya hadiah pada hari-hari tertentu, misalnya ketika lebaran; dan (e) pedagang mengerti benar kualitas barang dagangannya, sehingga dapat memberikan informasi dan mengarahkan pembeli pada barang yang terbaik. Hal seperti inilah yang tidak akan didapatkan oleh pembeli apabila mereka berbelanja di retail modern.

Sebenarnya berdasarkan pendapatan, segmen pasar dapat dibedakan menjadi 5 kelompok yaitu (Tambunan, 2004), Adapun model pengembangan pasar tradisional berbasis perilaku konsumen adalah integrasi dari 3 faktor yang saling berhubungan yaitu pembeli, pedagang dan pemerintah, sehingga tercipta pasar tradisional yang aman, nyaman, lengkap dan bersih.

\section{Kesimpulan dan Saran}

Kesimpulan yang dapat ditarik dari 
penelitian ini adalah terdapat empat faktor yang mempengaruhi pengembangan usaha pedagang Pasar Peterongan diantaranya, modal psikologis entrepreneur, karakteristik entrepreneur, inovasi, manajemen sumber daya manusia, dan karakteristik UKM. Pengembangan usaha pedagang Pasar Peterongan tidak berkaitan dengan jenis kelamin dari para pedagang, pedagang beranggapan tidak adanya perbedaan gender untuk menjadi pedagang di Pasar Peterongan. Pedagang sebagian besar sudah berdagang lebih dari sepuluh tahun sehingga pedagang memiliki pengalaman untuk bertahan dan tetap menjadi pedagang di Pasar Peterongan. Pedagang merasa keuntungan yang diperoleh tidak begitu terlihat bertambah setiap bulan dan tahunnya dikarenakan selalu dipergunakan sebagai modal kembali mengingat sering terjadinya kenaikan harga kebutuhan yang tak terduga.

Adapun hasil analisis faktor pembeli terdapat tiga faktor yang mempengaruhi keputusan pembelian konsumen Pasar Peterongan diantaranya, faktor sosial budaya, psikologis dan bauran pemasaran. Konsumen yang berbelanja di Pasar Peterongan tidak dipengaruhi oleh pengalaman yang diturunkan oleh orangtua. Kebanyakan dari konsumen yang berbelanja di Pasar Peterongan memilih Pasar Peterongan sebagai tempat berbelanja karena lokasi pasar yang tidak jauh dari rumah mereka. Namun ada juga konsumen yang bertempat tinggal jauh dari lokasi Pasar Peterongan dan memilih Pasar Peterongan sebagai tempat berbelanja karena kualitas barang yang dijual di pasar ini lebih baik jika dibandingan dengan pasar lain dan kebanyakan konsumen ini adalah pedagang makanan yang berbelanja untuk kebutuhan dagangannya. Selain itu produk yang dijual di Pasar Peterongan juga dinilai konsumen lebih lengkap jika dibandingan dengan pasar yang lain dan harga yang ditawarkan sama dengan pasar yang lain.

Pemerintah mempunyai peran dalam pembangunan Pasar Peterongan, hal ini sesuai dengan Peraturan Daerah Kota Semarang Nomor 9 Tahun 2013 tentang Pengaturan Pasar Tradisional. Pemerintah Kota Semarang berupaya membangun Pasar Peterongan sesuai dengan kebutuhan konsumen dan para pedagang. Pembangunan pasar juga tetap mempertahankan bangunan konservasi Kota Semarang dan pengadaan ruang terbuka hijau sehingga menjadi perpaduan pasar tradisional dan ruang terbuka hijau di sekitar pasar yang tidak merusak saluran air di masyarakat.

Untuk itu faktor-faktor yang membentuk Model Pengembangan Pasar Tradisional berbasis pada perilaku konsumen adalah integrasi dari 3 faktor yang saling berhubungan yaitu pembeli, pedagang dan pemerintah, sehingga tercipta pasar tradisional yang aman, nyaman, lengkap dan bersih.

Saran yang diberikan dalam penelitian ini adalah Pasar Peterongan sebaiknya melakukan pengelompokan lokasi kios pedagang kedalam jenis barang yang dijual. Hal tersebut dimaksud agar konsumen lebih nyaman dalam berbelanja dan mudah untuk mencari barang tertentu selain itu perlu dipertimbangkan tata letak kios pedagang bagi kemudahan pedagang dan konsumen. Apabila dibangun menjadi dua lantai, maka perlu dipertimbangkan adanya tangga khusus troley untuk mengangkut barang dagangan dan belanjaan konsumen dalam jumlah besar.

Adanya ruang terbuka hijau dan area parkir kendaraan sebaiknya dikelola langsung oleh pemerintah. Hal ini untuk menghindari adanya pungutan liar yang dilakukan oleh oknum-oknum yang tidak bertanggung jawab. Perlunya dibuat kebijakan yang bersifat bottom up terutama untuk pembangunan revitalisasi pasar dengan melibatkan pedagang maupun pembeli sehingga pembangunan pasar lebih mengedepankan aspek-aspek yang diinginkan oleh pedagang dan pembeli sebagai stakeholder dari pasar tradisional.

\section{Daftar Referensi} Tradisional.
http://antarajateng.com/detail/index
diunduh pada tanggal 7 April 2012 jam 19:43.

A.C.Nielsen. (2007). Kajian Dampak Ekonomi Keberadaan Hypermarket Terhadap ritel/pasar tradisional. Error! 
Hyperlink reference not valid. Diunduh tanggal 8 April 2012 jam 19.37.

Bappeda. (2010). Masterplan Pengembangan Pola Perpasaran Kota Semarang http://bappeda.semarang.go.id/uploaded/ publikasi/Pola_Perpasaran.pdf. diunduh pada tanggal 6 April 2012 jam 22:34.

Ekapribadi, Wildan. (2007). Pasar Modern: Ancaman bagi Pasar Tradisional. http://bimandiri.wordpress.com/2007/11/ 08/pasar-modern-ancaman-bagi-pasartradisional. diunduh pada tanggal 8 April 2012 jam 19.30 .

Trisno, Iwan. (2011). Eksistensi Pasar Tradisional di tengah Pesona Pasar Modern.

http://litbang.patikab.go.id/index.php?opt ion $=$ com content $\&$ view $=$ article $\&$ id $=108$ : eksistensi-pasar-tradisional-ditengahpesona-pasar-moder.diunduh tanggal 7 April 2012 jam 12.00.

Kotler, Philip. (1997). Marketing Management: Analysis, Planning, Implementation, and Control. Ninth
Edition. New York: Prentice-Hall.

Kusdarjito, Cungki. (2009). Menyoal Pasar Tradisional di Perkotaan. http://www.bapeda.pemdadiy.go.id/detail .php/index/Menyoal-pasar-tradisional-di perkotaan. diunduh tanggal 6 April 2012 jam 14.30

Paesoro, Adri. (2007). Pasar Tradisional di Era Persaingan Global. http://www.Smeru.or.id. diunduh tanggal 7 April 2012 Jam 15:46

Tambunan, Tulus, dkk. (2003). Kajian Persaingan Ritel. Penelitian KPPU Jakarta, Hal: 5-23.

Wiboonponse, Aree dan Songsak Sriboonchitta. (2006). Mengamankan Partisipasi Produsen Kecil dalam Sistim Agro-Makanan Nasional dan Regional Yang Terestrukturisasi: Kasus Thailand. Regoverning Markets [online]. http://www.regoverningmarkets .org/read/29/10/2010 diunduh tanggal 7 April 2012. 